\title{
Comparative Performance Analysis of Private and Public Companies' in the Oil Industry Sector: Russia and the World
}

\author{
Dmitry Rodnyansky ${ }^{1}$, Oksana Polyakova ${ }^{2}$, Ruslan Abramov ${ }^{3}$, Ivan Makarov ${ }^{4}$ \\ Department of state and municipal governance, Institute of management, economics and finance, Kazan Federal University, \\ 420008, Kazan, Russia, \\ ${ }^{*}$ Associate Professor, PhD, Institute of Management, Economics and Finance, Kazan Federal University, \\ SCOPUS ID 55776823700, ORCID ID 0000-0003-1389-1503 \\ ${ }^{2}$ Associate Professor, PhD, Institute of Management, Economics and Finance, Kazan Federal University, \\ SCOPUS ID 56539626000, ORCID ID 0000-0003-0719-3071 \\ ${ }^{3}$ Professor, PhD, Plekhanov Russian University of economics, SCOPUS ID 56291991700, ORCID ID 0000- \\ 0002-1736-5693 \\ ${ }^{4}$ Associate Professor, PhD, Financial university under the government of the Russian Federation, Lipetsk branch, \\ SCOPUS ID 57208418336, ORCID ID 0000-0002-7698-1875
}

\begin{abstract}
The paper analyzes the operations of Russian largest state and private oil companies. The authors researched whether Russian companies comply with OECD guidelines on corporate governance of state-owned enterprises. During the analysis of variance, the relationship between this parameter and the economic development indicators of a state-owned enterprise was found, namely, revenue and EBITDA. In addition, based on the DEA methodology, a two-stage analysis of the comparative effectiveness of the largest oil companies was carried out. The first stage identified the top efficient companies in the Russian oil industry. At the second stage, the operations of Russian companies were compared with the largest oil enterprises in the USA, Great Britain, China, Norway, the Netherlands and France. The authors found the three most efficient companies from the initially selected business structures. They proposed an effective company as a benchmark for each "inefficient" one, and offered to transform input and output parameters to achieve efficiency.
\end{abstract}

Keywords: Oil industry, state-owned companies, management efficiency, DEA analysis, private enterprises.

\section{INTRODUCTION}

The modern business world can be characterized by several divergent trends. On the one hand, the private sector is expanding in some states, and the number of small enterprises and individual entrepreneurs or the so-called self-employed is growing. On the other hand, there is a clear trend to globalize state-owned companies and to change their status to transnational state-owned corporations. The mentioned trend is characteristic for developing countries, such as China, Russia, Brazil, India, as well as for the countries with developed economies - Norway, France, Italy, and South Korea. The largest number of transnational state-owned corporations is in the energy sector, namely in the nuclear industry, oil production and refining, transportation of oil, gas and oil products.

According to a number of studies, in 2010 there were at least 650 multinational state corporations with more than 8,500 branches, of which $44 \%$ were from the developed countries. For this reason, it can be concluded that the assumption that conventional "state capitalism" is typical only for developing countries with predominantly authoritarian governance is invalid.

At the same time, the establishment and development of transnational state corporations have not yet been studied to a large extent in the academic literature. Along with research conducted at the end of the 20th century, the approach described by American scholars in 2014 is considered thought-provoking $[3 ; 6]$.

They explain a small sample of research on state-owned transnational corporations by the influence of the concept that there is a confrontation between the business and the state. In fact, in their work, the authors were the first to propose to exploit the extraterritoriality principle when analyzing stateowned companies, which allowed a much broader assessment of the patterns and mechanisms used by these structural units in their development.

Other researchers in their studies show a significant impact of state-owned multinational companies on the development of industries, regions and the global economy as a whole $[1 ; 8$; 9]. In some papers, special attention of scholars is paid to the structural features and the specifics of such companies' interaction with public authorities [12], in others, performance indicators of state-owned companies and their comparison with private businesses are highlighted as the main scientific problem that requires further study $[7 ; 11]$.

Corporate social responsibility of state-owned companies is also often the subject of research by scientists around the world. Moreover, here there is no unequivocal opinion as well. Some authors believe that state-owned companies have 
a much greater responsibility for supporting the social sphere of the territories where they operate, while other authors do not consider the problem to be presented that way to be correct. However, the most popular in the academic literature is the theme of new state capitalism, when the state becomes not only an owner, but also an entrepreneur $[2 ; 4 ; 5 ; 10]$.

\section{MATERIAL AND METHODS}

One of the fundamental documents for managing state-owned companies is the OECD guidelines on corporate governance of state-owned enterprises. These principles highlighted seven main blocks of issues on which recommendations are given: rationale for state ownership, the state's role as an owner, relations with interested parties, shareholders, and transparency of information disclosure and particularities of the board of directors. Each of the seven blocks has a list of additional indicators that most fully reveal the essence of the selected block.

In the paper, the authors studied and analyzed the compliance of Russian state-owned oil companies with these recommendations. Eleven state-owned companies were selected as an object of research, whose main operations are associated with the Russian oil industry. All selected companies have the status of joint stock companies: PAO Rosneft, PAO Tatneft, PAO Transneft, PAO Gazprom Neft, PAO ANK Bashneft, PAO NGK Slavneft, AO Zarubezhneft, AO Arktikmorneftegazrazvedka, AO Nenetskaya neftyanaya companiya, PAO GEOTEK Seismorazvedka, AO Rosgeologiya. However, their management, ownership and shareholding structures are very different. The shares of some selected companies are listed on Russian and international exchanges, and capital stock is split into minority owners.

For some companies, the Russian Federation is the sole shareholder. PAO Rosneft has the most complex ownership structure and is not a state-owned company technically, since the Russian Federation owns the shares of the company through Rosneftegaz, another joint-stock company. However, due to the fact that PAO Rosneft is the largest taxpayer and leading oil company not only in Russia but in the world as well, and in fact it is a state-owned company, it was also included in the sample.

Table 1 shows all eleven selected companies, and includes seven blocks from OECD recommendations. In addition, the number of indicators that make up this block is shown opposite each block. Opposite each state-owned company, the corresponding column shows the number of indicators that, in the authors' opinion, is complied with by a particular organization. Moreover, based on the summation of all indicators, it was concluded whether these state-owned companies comply with the OECD guidelines.

Table 1. State-owned companies and their compliance with OECD requirements

\section{RESULTS}

At the next stage, the authors set the task to analyze how partial or full compliance with the OECD guidelines affects the economic performance of organizations. To solve this problem, analysis of variance was carried out in the Statistica application package. As a predictor factor, an indicator of compliance with the OECD Guidelines (Yes / No) was selected. From the point of view of the objectivity of the analysis, the most objective would be the indicator of the company's market capitalization as a dependent variable, however, among the eleven selected businesses, only six are listed on stock exchanges, the remaining companies have no market valuation, and there are no reports of valuation companies in the public domain. For this reason, EBITDA was chosen as the dependent variable. This indicator is more adequate in comparison with the indicator of profit before tax, net profit, and a number of others, since it eliminates the possible various approaches to accounting and policy.

Figure 1 shows the source data for the analysis.

\begin{tabular}{|l|r|l|}
\hline & EBITDA, billion & $\begin{array}{l}\text { compliance } \\
\text { with } \\
\text { principles } \\
\text { Oubles }\end{array}$ \\
\hline Rosneft & 2081 & yes \\
\hline Gazprom-neft & 780 & yes \\
\hline Tatneft & 294 & yes \\
\hline Transneft & 433 & yes \\
\hline Bashneft & 172 & yes \\
\hline Slavneft & 47 & no \\
\hline Zarubezhneft & 36 & no \\
\hline AMNR & 1 & no \\
\hline NNK & 0,4 & no \\
\hline Geotec & 2,4 & no \\
\hline Rosgeology & 2,7 & no \\
\hline
\end{tabular}

Figure 1. Resource data for analysis of variance by EBITDA

The results of a single-factor analysis of variance are shown in figure 2.

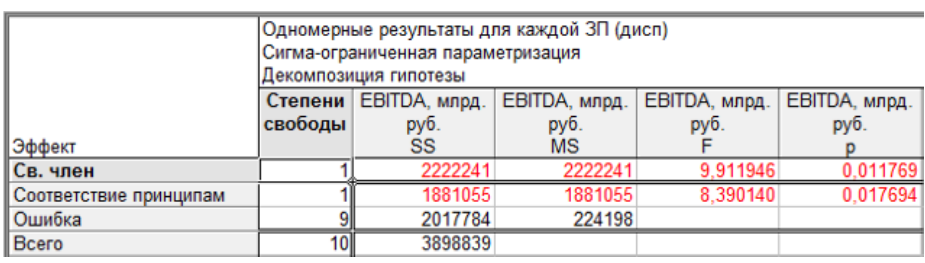

Figure 2. Results of a single-factor analysis of variance of state-owned companies in terms of EBITDA

As can be seen from figure 2, "Compliance with the OECD guidelines" is a significant effect. For convenience, significant effects $(\mathrm{p}<0.05)$ are highlighted in red. 
International Journal of Engineering Research and Technology. ISSN 0974-3154, Volume 13, Number 11 (2020), pp. 3469-3474

(C) International Research Publication House. https://dx.doi.org/10.37624/IJERT/13.11.2020.3469-3474

Similarly, a variance analysis was performed, where the dependent variable was the gross income of companies.

The results of the variance analysis are similar to the previous ones and are shown in Figure 3.

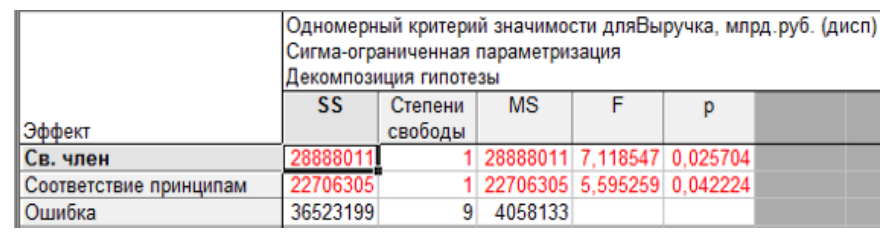

Figure 3. Results of a single-factor analysis of variance of state-owned companies upon the indicator Revenue

The selected predictor indicator "Compliance with OECD Guidelines" is also significant, and p does not exceed 0.05 .

Thus, it can be concluded that the compliance with the OECD guidelines on corporate governance for state-owned enterprises has an impact on the economic performance of companies, in particular, on EBITDA and gross income of the organization.

To study the operations of state-owned companies in more detail, the functioning of the largest Russian private and state companies was compared with functioning of foreign private and state-owned ones. At the first stage of the analysis, a comparison was made only between Russian state-owned and private entities operating in the oil industry of the Russian Federation. So, from the afore-mentioned list, four stateowned companies were selected - PAO Rosneft, PAO Tatneft, PAO Gazpromneft and PAO Bashneft. PAO
Transneft was excluded from the list of companies for comparison due to the specifics of the services provided, as well as companies whose shares are not listed on stock exchanges and do not provide full information about their activities. The comparative analysis also involved two Russian private companies - PAO Lukoil and PAO Surgutneftegas. In total, six analyzed Russian companies account for more than $80 \%$ of the Russian oil production and refining market, which does not require to include small oil companies in the analysis, since it is difficult to find information about them.

At the second stage, the largest foreign companies - stateowned Petrochina, Sinopec (China), Petrobras (Brazil), Equinor (Norway) and private ones - ExxonMobil, Chevron (USA), "BP" (UK), "Royal Dutch Shell" (UK, Netherlands) and "Total" (France) were selected for comparative analysis.

Key production and economic indicators of enterprises for the period from 2014 to 2018 were analyzed. All values are shown in US dollars based on weighted average exchange rates for each period. The market capitalization ratio is calculated based on the average capitalization of each company over 5 years from 2014 to 2018. Since in foreign practice the oil production is usually measured in million barrels per day, for convenience, the volume of oil production is converted into million tons based on the average density of each brand of oil produced. The source data are shown in Table 2 .

Table 2. Key indicators of leading Russian and foreign oil companies

\begin{tabular}{|c|c|c|c|c|c|}
\hline Company & $\begin{array}{l}\text { EBITDA 2014-2018, } \\
\text { billion dollars }\end{array}$ & $\begin{array}{c}\text { Revenue, billion } \\
\text { dollars }\end{array}$ & $\begin{array}{l}\text { Oil production } \\
\text { mln tons }\end{array}$ & $\begin{array}{l}\text { Average capitalization } \\
\text { billion dollars }\end{array}$ & $\begin{array}{l}\text { Average dividend } \\
\text { yield, } \%\end{array}$ \\
\hline Rosneft & 124,2 & 536,5 & 1072,7 & 56,6 & 4,1 \\
\hline Gazprom neft & 44,5 & 172,0 & 295,4 & 19,0 & 5,5 \\
\hline Tatneft & 16,3 & 56,3 & 140,8 & 16,6 & 6,8 \\
\hline Bashneft & 12,1 & 60,7 & 99,1 & 6,1 & 7,9 \\
\hline Lukoil & 76,3 & 545,5 & 464,5 & 46,8 & 6,3 \\
\hline Surgutneftegaz & 29,9 & 104,8 & 306,2 & 22,6 & 2,3 \\
\hline Exxon Mobile & 229,8 & 1403,7 & 724,3 & 320,4 & 3,5 \\
\hline $\mathrm{BP}$ & 102,8 & 1319,3 & 746,6 & 106,5 & 5,7 \\
\hline Chevron & 160,9 & 772,7 & 666,4 & 192,0 & 3,9 \\
\hline Equinor & 115,3 & 345,3 & 501,0 & 59,6 & 0,1 \\
\hline Sinopec & 125,9 & 1861,5 & 217,6 & 76,4 & 5,2 \\
\hline Petrobras & 102,1 & 506,7 & 513,0 & 54,5 & 2,5 \\
\hline Total & 134,0 & 816,5 & 611,7 & 114,2 & 4,7 \\
\hline Royal dutch shell & 228,9 & 1652,0 & 848,1 & 196,5 & 6,4 \\
\hline Petrochina & 242,4 & 1546,6 & 629,4 & 132,1 & 2,7 \\
\hline
\end{tabular}


The analysis was based on Data envelopment analysis (DEA) methodology that identifies the relative effectiveness of the objects in question depending on the "input" and "output" parameters of the model. Maxdea program was used to perform the analysis.

So, at the first stage, only national oil companies were analyzed. The indicator "Oil production" was determined as the "input" parameter. In fact, this is the only indicator that the state can have a direct impact on through international production agreements, a quota and licensing system, holding auctions for field development, etc. All other indicators depend on decisions made in companies, on their efficiency and effectiveness. Table 3 summarizes the results of the analysis by the DEA methodology for Russian private and state-owned oil companies

Table 3. The results of Data envelopment analysis of Russian companies

\begin{tabular}{|l|c|c|}
\hline \multicolumn{1}{|c|}{ Company } & $\begin{array}{c}\text { Efficiency } \\
\text { coef }\end{array}$ & Benchmark \\
\hline Rosneft & 0,737323 & Lukoil \\
\hline Gazprom neft & 0,941117 & Bashneft \\
\hline Tatneft & 1 & \\
\hline Bashneft & 1 & \\
\hline Lukoil & 1 & \\
\hline Surgutneftegaz & 0,784092 & Lukoil \\
\hline
\end{tabular}

\section{SUMMARY}

Thus, in accordance with the analysis, we can conclude that three companies are relatively effective in the parameters under consideration - Tatneft, Bashneft, Lukoil - with efficiency ratios of 1 . Opposite each of the three relatively less efficient companies we place the name of the company that is the target benchmark in terms of improving efficiency. LUKOIL is the closest benchmark for Surgutneftegaz and Rosneft, while Bashneft is the closest benchmark for Gazpromneft. At the second stage, foreign companies were included in the analysis as well. The results are presented in Table 4.

Table 4 presents the companies similarly to the previous table, and the second column shows the coefficients of companies' comparative efficiency. Thus, as a result of solving the optimization problem of outputs when comparing fifteen Russian and foreign private and state oil companies, three companies were recognized as effective - two stateowned companies Sinopec (China) and PAO NK Bashneft (Russia) and ExxonMobil, US private company.

The adjacent columns also indicate the target values of the first two "output" indicators - gross income and EBITDA. The closer to 0 is the company's performance ratio, the greater is the gap between the actual and target gross income and EBITDA. Thus, we can say it is these indicators that, given the "input" parameters, the lagging organizations need to achieve in order to increase their effectiveness.

Table 5 presents companies with target values of capitalization indicators and the level of dividend yield.

Table 4. The results of DEA of Russian and foreign companies

\begin{tabular}{|l|c|c|c|c|c|}
\hline \multicolumn{1}{|c|}{ Company } & $\begin{array}{c}\text { Efficiency } \\
\text { coef }\end{array}$ & $\begin{array}{c}\text { EBITDA, billion } \\
\text { dollars }\end{array}$ & $\begin{array}{c}\text { Target EBITDA, billion } \\
\text { dollars }\end{array}$ & $\begin{array}{c}\text { Revenue } \\
\text { billion dollars }\end{array}$ & $\begin{array}{c}\text { Target revenue, } \\
\text { billion dollars }\end{array}$ \\
\hline Rosneft & 0,200079 & 124,2 & 620,6 & 536,5 & 9176,6 \\
\hline Gazprom neft & 0,390069 & 44,5 & 114,0 & 172,0 & 1538,9 \\
\hline Tatneft & 0,778772 & 16,3 & 37,2 & 56,3 & 435,1 \\
\hline Bashneft & 1 & 12,1 & & 60,7 & 3061,7 \\
\hline Lukoil & 0,360659 & 76,3 & 216,3 & 104,8 & 2292,6 \\
\hline Surgutneftegaz & 0,236056 & 29,9 & 158,3 & 1403,7 & \\
\hline Exxon Mobile & 1 & 229,8 & & 1319,3 & 5394,5 \\
\hline BP & 0,386131 & 102,8 & 392,7 & 345,3 & 2184,4 \\
\hline Chevron & 0,679576 & 160,9 & 246,6 & 1861,5 & 4285,8 \\
\hline Equinor & 0,397763 & 115,3 & 289,8 & 506,7 & 4388,5 \\
\hline Sinopec & 1 & 125,9 & & 816,5 & 3562,7 \\
\hline Petrobras & 0,343987 & 102,1 & 296,8 & 1652,0 & 4668,5 \\
\hline Total & 0,480175 & 134,0 & 388,5 & 1546,6 & 5384,3 \\
\hline $\begin{array}{l}\text { Royal dutch } \\
\text { shell }\end{array}$ & 0,589127 & 228,9 & 364,1 & & 5 \\
\hline Petrochina & 0,665639 & 242,4 & & & 5 \\
\hline
\end{tabular}


International Journal of Engineering Research and Technology. ISSN 0974-3154, Volume 13, Number 11 (2020), pp. 3469-3474

(C) International Research Publication House. https://dx.doi.org/10.37624/IJERT/13.11.2020.3469-3474

Table 5. The results of DEA of Russian and foreign companies on market cap and dividend yield

\begin{tabular}{|c|c|c|c|c|c|}
\hline Company & Efficiency coef & $\begin{array}{c}\text { Market cap, billion } \\
\text { dollars }\end{array}$ & $\begin{array}{c}\text { Target market cap, } \\
\text { billion dollars }\end{array}$ & $\begin{array}{l}\text { Dividend yielld } \\
\text { billion dollars }\end{array}$ & $\begin{array}{l}\text { Target dividend } \\
\text { yield, billion dollars }\end{array}$ \\
\hline Rosneft & 0,200079 & 56,6 & 376,7 & 4,1 & 25,4 \\
\hline Gazprom neft & 0,390069 & 19,0 & 67,6 & 5,5 & 13,9 \\
\hline Tatneft & 0,778772 & 16,6 & 21,3 & 6,8 & 8,7 \\
\hline Bashneft & 1 & 6,1 & & 7,9 & \\
\hline Lukoil & 0,360659 & 46,8 & 129,8 & 6,3 & 17,4 \\
\hline Surgutneftegaz & 0,236056 & 22,6 & 95,6 & 2,3 & 9,5 \\
\hline Exxon Mobile & 1 & 320,4 & & 3,5 & \\
\hline $\mathrm{BP}$ & 0,386131 & 106,5 & 275,8 & 5,7 & 14,8 \\
\hline Chevron & 0,679576 & 192,0 & 282,4 & 3,9 & 5,7 \\
\hline Equinor & 0,397763 & 59,6 & 175,9 & 0,1 & 11,8 \\
\hline Sinopec & 1 & 76,4 & & 5,2 & \\
\hline Petrobras & 0,343987 & 54,5 & 180,1 & 2,5 & 12,1 \\
\hline Total & 0,480175 & 114,2 & 376,7 & 4,7 & 9,7 \\
\hline Royal dutch shell & 0,589127 & 196,5 & 67,6 & 6,4 & 12,7 \\
\hline Petrochina & 0,665639 & 132,1 & 21,3 & 2,7 & 14,9 \\
\hline
\end{tabular}

\section{CONCLUSION}

To conclude, the results of the analysis demonstrate that, under equal conditions, with comparable "input" resources which are taken into account in the model in the form of oil production, companies have different effects on raw materials and get different results at the output. The objectivity of this model is also enhanced by the fact that the analysis was performed not for 1 year, but on an accrual basis over the past 5 years. The specified period minimizes the impact of crisis factors, and considers various long-term investments in planning, survey, and geological exploration.

Also important is the fact that there are state-owned companies among the effective companies. Despite the prevailing in some papers opinion that only private businesses are really effective, the authors' model demonstrates that when having a well-structured management system, stateowned companies can be more efficient and effective.

It is especially worth noting that one of the most effective companies was the Russian PAO NK Bashneft. One of the reasons for the high efficiency of this company, in our opinion, is the fact that the organization is a major member of the territorial innovation cluster of the Republic of Bashkortostan.

\section{ACKNOWLEDGEMENTS}

The work is performed according to the Russian Government Program of Competitive Growth of Kazan Federal University.

\section{REFERENCES}

[1] Aslanli K. Fiscal sustainability and the state oil fund in Azerbaijan. Journal of Eurasian Studies. 2015 Jul $1 ; 6(2): 114-21$.
[2] Clò S, Fiorio CV, Florio M. The targets of state capitalism: evidence from M\&A deals. European Journal of Political Economy. 2017 Mar 1;47:61-74.

[3] Cuervo-Cazurra A, Inkpen A, Musacchio A, Ramaswamy K. Governments as owners: State-owned multinational companies. Journal of international business studies. 2014:919-942.

[4] Estrin S, Liang Z, Shapiro D, Carney M. State capitalism, economic systems and the performance of state owned firms. Acta Oeconomica. 2019 Jan;69(s1):175-93.

[5] Karolyi GA, Liao RC. State capitalism's global reach: Evidence from foreign acquisitions by state-owned companies. Journal of Corporate Finance. 2017 Feb $1 ; 42: 367-91$.

[6] Knutsen CH, Rygh A, Hveem H. Does state ownership matter? Institutions' effect on foreign direct investment revisited. Business and Politics. 2011 Apr;13(1):1-31.

[7] Lynn LEJR, Robichau RW. Governance and organization effectiveness : towards atheory of government performance. Journal og Public Police. 2013;33(2): 201-228.

[8] Antolín MJ, Cendrero JM. How important are national companies for oil and gas sector performance? Lessons from the Bolivia and Brazil case studies. Energy Policy. 2013 Oct 1;61:707-16.

[9] Marques LM, FS Gaspar AT, Schiozer DJ. Impact of the New Brazilian Fiscal System on Development of Oil Production Strategy. InSPE Asia Pacific Oil \& Gas Conference and Exhibition 2014 Oct 14. Society of Petroleum Engineers.

[10] Musacchio A, Lazzarini SG, Aguilera RV. New 
International Journal of Engineering Research and Technology. ISSN 0974-3154, Volume 13, Number 11 (2020), pp. 3469-3474

(C) International Research Publication House. https://dx.doi.org/10.37624/IJERT/13.11.2020.3469-3474

varieties of state capitalism: Strategic and governance implications. Academy of Management Perspectives. 2015 Feb;29(1):115-31.

[11] Rodnyansky DV, Abramov RA, Repin ML, Nekrasova EA. Estimation of innovative clusters efficiency based on information management and basic models of data envelopment analysis. International Journal of Supply Chain Management. 2019; 8(5): 929-936.

[12] Thurber MC, Hults DR, Heller PRP. Exporting the «Norwegian Model»: The effect of administrative design on oil sector performance. Energy Policy. 2011;39:5366-5378. 